\title{
Social Identity in The Tattooed Girl ${ }^{*}$
}

\author{
WANG Xiao-dan \\ Harbin Normal University, Harbin, China
}

\begin{abstract}
The relationship between social class and social identity is that, on one hand, social identity is linked to social class and class distinction plays the most important role in determining social identity; and on the other hand, social identity stresses the individual's subjective feelings and it refers to the perception of the individual. What is important is the effect of the psychological essence of social identity. In Oates's The Tattooed Girl (2004), an individual's perception of social identity has an impact on his or her behavior that causes conflicts between the characters. This paper will analyze the issue of social identity in The Tattooed Girl from the following aspects: How the lower class with a subordinate social identity experiences the personal struggles; How the middle class with a privileged social identity undergoes spiritual suffering due to the traumatic memory; And how the less advantaged attempts to break the social identity boundary, and how such efforts lead to tragedy.
\end{abstract}

Keywords: The Tattooed Girl, social identity, social class, tragedy

\section{Introduction}

To explore American society in different historical context has been one of Oates's major concerns in her literary writing (Bender, 1987, p. 6). Her examination of American society and her excellent artistry have found their expression in her early works in which the "stark, violent contemporary realism" is depicted (Johnson, 1998, p. 305). Similarly, in The Tattooed Girl (2004), Oates yet again puts what she scrutinizes in society into her fictional recreation along with her fascination with human psychological complexity. However, this novel hardly stands as a monotonous repetition of her concern. In the text, Oates has dramatized social reality "in terms of the distribution of power among institutions” (Daly, 1996, p. x). It is the distribution of power that provokes social conflicts between a privileged social group and a marginalized social group. In other words, Oates's body of work lends itself well to the analysis that the social conflicts exposed in the text are in relation to class stratification. Besides, by applying a third-person omniscient narrator, the text not only offers us a chance to probe the psychological complexity of the characters, but exhibits the characters' perception of membership in certain social class. Their perception of group membership is where social identity originates.

Therefore, in what follows, the author will analyze in detail the issue of social identity in The Tattooed Girl, and her interpretation of social identity is mainly based on the class distinction of the characters. The Tattooed Girl depicts the story between the male character Seigl and the female character Alma. Seigl is a celebrated but

\footnotetext{
* Acknowledgments: This paper is part of the result of the research programs the author hosts, Identity and Space: The Case Study of Spatial Narration in Contemporary American Literature. No. 11C028, Heilongjiang Philosophy and Social Sciences Project.

WANG Xiao-dan, Ph.D., associate professor, School of Western Languages and Literatures, Harbin Normal University.
} 
reclusive writer, as well as a professor at a university. The narration starts from the day when Seigl decides to hire an assistant. After having refused several competent applicants, he reluctantly hires a young assistant Alma with a tattoo on her face. Ostensibly the purpose of hiring an assistant is to reduce his professional burden while the hidden purpose is to erase his personal affair stress as Seigl suffers from physical and spiritual pains due to his declining body and his traumatic memories of the family past. As the tattooed Alma is involved deeper and deeper in his life, Seigl does not realize that he has brought into an enemy into his life, who eventually leads to his death.

Consequently, the author will analyze the issue of social identity in The Tattooed Girl from the following aspects: How the lower class with a subordinate social identity experiences the personal struggles; How the middle class with a privileged social identity undergoes spiritual suffering due to the traumatic memory; And how the less advantaged attempts to break the social identity boundary, and how such efforts lead to tragedy.

\section{Personal Struggles and Social Identity}

Alma in The Tattooed Girl is such an individual who "attempts to survive in a confusing and dangerous world". Oates has explained her characterization of Alma in the novel: "Alma—the girl of the title-is 'an American type'. She's from a background that's very poor, uneducated, very bigoted” (Farry, 2004, p. 12). Her social identity as a member of the lower class allots her a marginalized status in the social ladder.

By using a metaphor of flotsam, Oates presents vividly how an individual of a subordinate social identity is marginalized by the mainstream community dominated by the middle class. Alma is like "debris" on a river bank. Weak as she is, Alma arouses the "predator's senses" (Oates, 2004, p. 23). Having been refused by the "voices" and "faces", Alma roams the streets and arrives at The Café where the "predator" Dmitri Meatte works as a waiter.

Oates deepens her references to the marginalization and subordination status of Alma in the social ladder by detailing the story between Alma and Dmitri. Dmitri is regarded as a "servant" in a subordinate position in the hierarchy of social identity by his middle-class customer Seigl. However, when Dmitri and Alma are together, he occupies the dominant position over Alma. When Dmitri notices Alma for the first time, Alma seems to be "ejected". It is apparent that Alma is akin to a sex object in Dmitri's eyes. If we examine Dmitri's observation in relation to gender, it is not difficult to find Dmitri the male "objectifies" Alma the female through his "gaze” as he uses his own gaze to "frame” Alma as "a passive object” who is "devalued" and afflicted with violence and sadism (Cavallaro, 2001, p. 137). Alma's socialization as a sex object is the sign of male dominance over women. To Dmitri, Alma is just a female "mollusk" that is "boneless" and weak, a female "that's big soft floppy breasts all over" (Oates, 2004, p. 57), a female that is powerless and is easily surrendered to violence.

Oates makes it clear that it is class stratification that separates Alma from other white women. As a proletarian, Alma's subordination is reinforced by the violence inflicted upon her by males of lower class. In addition, no where does Oates write more strongly about Alma's marginalized status in the social identity hierarchy than in the economic and social contrast between Alma and Seigl.

Alma calls herself “an American” (Oates, 2004, p. 142), yet she is not the same “American” as Seigl is. Seigl is from a well-to-do family. His rich parents died years ago, and they have left a multitude of property to Seigl including many high-priced houses in some areas. Seigl's house is located in the "most distinguished old 
residential neighborhood" of the city. It is so spacious that Seigl just uses a few of the furnished rooms "as a squatter might have done” (Oates, 2004, p. 16). At the same time, both Seigl and his older sister Jet are trust-fund beneficiaries of the family estate. Born by parents of a "mixed" marriage of Protestant and Jew, Seigl's full name is Joshua Moses Seigl, named for "his father's father who has been a rich importer of leather goods in Munich, Germany in the 1920s and 1930s” (Oates, 2004, p. 7). His sister Jet has self-named herself “Jet Steadman-Seigl”, rejecting her baptized name in a Presbyterian church, because her old name lacks "the manic glamour" and must "be cast off". Her new name "Steadman" is their mother's surname which has "signaled inherited money and social position in the Rochester area since 1880s" (Oates, 2004, p. 7). For the characters in The Tattooed Girl, their last names serve as a symbol of inheritance, social status, and social identity, or lack of it. In contrast to the name of "Seigl" that functions as the sign of "inherited money and social position", Alma does not have a last name. As for Dmitri, another character of the lower class, his last name is Meatte but there is "no romance or mystery to Meatte" (Oates, 2004, p. 24). Besides, Seigl has a teaching position at the University of Rochester and he is celebrated in the academic circles. He is also a "self-sustaining” and "self-sufficient” writer of many popular and academic books. Seigl enjoys fame, wealth, and prestige. To reinforce the contrast between Seigl and Alma, Oates lists the books that Seigl's reads in his bookcase, including Virgil's Aeneid, Joyce's Finnegans Wake, Erich Neumann's The Origins and History of Consciousness, Karl Jaspers's Reason and Existence, Carl Jung's The Archetypes and the Collective Unconscious, Herbert Marcuse's Eros and Civilization. When Alma reads the titles of the books that seem to be totally unknown to her, a strong sense of class consciousness strikes her as she is brought sharply to the awareness of the value system that measures and divides people in the hierarchy of social class.

\section{History, Memory, and Social Identity}

Being interviewed by Moment Magazine, Oates explains that one of the creative inspirations for the book The Tattooed Girl is her interest in human beings. The novel, as well as its theatre production, focuses on the dramatic interaction between people with whom she feels an emotional connection. Asked to comment on the character Seigl in the novel, Oates thinks he is "behaving like a Greek tragic hero" and the novel has "a background of Greek tragedy” (Farry, 2004, p. 12). In the author’s view, Oates has created the "Greek tragic hero" as a middle-class man who brings about his destruction through his own actions. In the text, Seigl hires Alma to be his assistant but he remains unaware that he has brought into his home a girl who hates him. Their closeness forces Seigl and Alma to make discoveries that cut to the core of their identities. In a sense, the dramatic interaction between Seigl and Alma is the conflict between people with different social identities.

One day Seigl falls suddenly in Mount Carmel Cemetery, and that is the beginning of his illness. The setting of cemetery in a symbolic light implies his final death. Seigl is diagnosed of nerves multiple sclerosis, and he is often dizzy and feels frequently weak in his limbs. Sometimes he has double vision in his eyes. Seigl's declining health is in sharp contrast to Alma's body that is fleshy, white, and healthy. Oates brings to the focus on the contrast of health between the two characters to imply that the sense of superiority established by the privileged social identity is destroyed. Seigl feels inferior in front of Alma's healthy body. He is "swallowing his pride" (Oates, 2004, p. 146) when he needs Alma's help to climb the slippery steps into his house.

To reinforce the connection between social identity and health, Oates depicts how Seigl feels amazed when 
he is well overnight all of a sudden. Doctor Friedman tries some new medications and treatment that are less powerful than the previous tests. There is no steroid in the new medications. These medications and treatment deal with his central nervous system disorders and diseases. After taking the medications, Seigl regains his strength and he can easily move his legs. The temporary recovery makes Seigl feel ecstatic, so he wants to "sob with relief" and wants to "laugh aloud" (Oates, 2004, p. 164). As a result, Seigl begins to care about his appearance. He shaves his whiskers, which makes him appear less exhausted and depressed in a naked and exposed face. His heavy cheeks, jowls, and chin are "red-smarting and swollen" (Oates, 2004, p. 163), and he looks refreshing. Seigl casts aside his fear and despair and regards his fear as "a ruse”, "a hoax", and "a cheat" (Oates, 2004, p. 166). He is a little shameful of overacting on his falling in the cemetery, and his fear and worries are "injurious to his pride" (Oates, 2004, p. 166). This pride, in fact, is the sense of superiority as a member of middle class with a dominant social identity.

When he is ill and weak, Seigl thinks by nature he is a "philosopher", because "philosophers hate history". To be a philosopher is "to wish to believe that the human mind transcends the contingencies of time" (Oates, 2004, p. 49), and philosophy is "of the timeless spirit", an art of space, rather than an art of time. In contrast, history is not of the timeless spirit, but "solidly of the earth" (Oates, 2004, p. 49). When Seigl recovers from his nerve disease, he thinks he is a "writer" again. History is not frightful any more and in his new novel, history is made spatial but not linear. Seigl will write about human beings who are no loner "opaque but transparent as jellyfish" in his new novel. Besides, Seigl plans to depict the souls that are "visible as quivering upright flames inside the skins and intricate skeletal structures of their bodies" (Oates, 2004, p. 171).

Owing to his recovery, Seigl reclaims his social identity as a prestigious professor and a celebrated writer. He is glad to participate in many book fairs invitation in many countries. He attends a symposium lecturing on a "fashionably esoteric” topic “The (Re)Discovery of the Body: Ancient and Modern Visions” (Oates, 2004, p. 263). He also brings himself to make a decision to visit Munich and Dachu someday. Seigl has never been to Munich and Dachu "out of a dread of vertigo" caused by his fear of history, and only when he recovers from illness, can he have the courage to recall his "origin" (Oates, 2004, p. 264). To recall his origin is to face the past and history. Seigl realizes if Karl Seigl had not been sent away by his desperate parents in 1939 and had not be taken in by relatives in New York City, "how could not Joshua Seigl coming into existence twenty-five years later" (Oates, 2004, p. 264). Seigl admits that the refutation of personal history is the denial of self. However, Seigl's health is worsening after the temporary recovery. A "Greek tragic hero" as he is, death seems to be inevitable. Oates describes Seigl's academic activities of book fairs and new plans of writing as his "posthumous" life.

Seigl's role in The Tattooed Girl is remarkably complex. Oates portrays him as a man who is unable to cover up his physical and emotional pains. As a member of the middle class, Seigl does not suffer materially from struggling for survival, however, he undergoes spiritual suffering due to his traumatic memory of the family past. Besides, his spiritual suffering is reinforced because his declining health destroys his sense of superiority brought out by his privileged social identity.

\section{“The Shadows" of Death and Social Identity Conflict}

As the author of The Shadows, Seigl scarcely speaks of the theme of his novel. While the applicant Essler explains that he thinks the novel remains to him the most haunting because it is elliptical and poetic. Essler 
believes in the novel the writer has created "the shadows of things" but not the things themselves. Readers are forced to imagine what the writer does not reveal and they become collaborators "in shadows" (Oates, 2004, p. 10). Seigl is surprised at Essler's explanation because it is so close to what he has intended in the novel. In a sense, Seigl has written so poetically about others' death in his work The Shadows, the title of which serves as a prophecy of his own tragedy of death in the end of The Tattooed Girl.

In The Tattooed Girl, Oates employs the love-hate relationship between the middle-class employer and the economically and socially disadvantaged assistant so as to suggest that tragedy is caused by the conflicts between different social classes. Moreover, Oates creatively presents how the subordinate social class makes a utopian effort to break social identity boundary, which brings out the deaths of both characters.

Doctors diagnose Seigl as having a genetic fault and his nerve disease is hereditary. But this is not enough to account for Seigl's death. Seigl dies of class hatred simmered behind Alma's silence. Oates depicts Alma as an assistant who hates secretly her employer, though her employer is not exploitative and treats her courteously and generously. Alma hates Seigl because he is rich and has money but does not spend it. In the drawer Alma finds many checks worth thousands of dollars but Seigl never endorses and cashes them because he has never known about them. Alma hates Seigl because he does not know what he owned. "Like a blind man his eyes were turned inward; like a deaf man he heard only the sound of his own voice inside his head” (Oates, 2004, p. 152). Seigl's indifference to what he owns irritates Alma because she grows up in poverty.

Alma does not think Seigl has done "any actual work". He seems not to have any teaching work as Alma supposes a university professor should do. Since Alma lives in Seigl's house, she has the chance to observe the life style of the middle class. She finds Seigl's groceries are delivered and trees are trimmed after a windstorm. Snow is shoveled for him and the "chipped and cracked" plates are not cherished though they are expensive china. Seigl does not use his washing machine and drier and he sends out his laundry every week to Mount Carmel Laundry \& Dry Cleaners, including his undershirts, shorts, pajamas, towels, and sheets, and all are sent back ironed. The laundry charges Seigl about as much as Alma makes in a week. Alma is shocked at the luxurious middle-class life style and she attributes it to a Jewish tradition of "spoiling the men" (Oates, 2004, p. 152).

Moreover, not only the middle-class life style that astonishes the member form lower class is depicted, but the contrast in education is highlighted to account for Alma's sense of inferiority about her social identity. Alma has dropped out of her middle school and receives little education. Though Seigl has explained it, Alma can not understand why the mails address "Dr. Joshua Seigl" because she thinks he is not "medical doctor" (Oates, 2004, p. 152). Alma does not have a reading habit and she regards Seigl's "manuscripts” as "hot shit” (Oates, 2004, p. 149) and his study room is like "a graveyard” in damp weather (Oates, 2004, p. 154). At Seigl's birthday party, Alma finds that her employer has so many friends, some of whom are proposing a toast to Seigl with wine glass "like people on TV". The toast they propose is of a mystery for Alma because she does not know people can speak words fluently in this way. She guesses that these people have "prepared" the toast and they are "reading" their words. Their eloquence makes Alma feel "so stupid" because her very tongue is "fat and sluggish in her mouth". The language they speak is surely English, but it seems "foreign” to Alma (Oates, 2004, p. 212). When Seigl concentrates on his translation of Virgil and enjoys reciting the poetry, Alma thinks he is showing his pride as if he does not know "anybody else exists", and she is disgusted "seeing a man like that unaware of another human being in his house” (Oates, 2004, p. 156). Alma feels her rage building up inside her when Seigl 
considerately tells her to take an evening off. Alma thinks Seigl is speaking in an ironic tone because in fact there is not "a life of Alma Busch's", not a place "where people await her" (Oates, 2004, p. 183). The misunderstanding is not a personal matter, but an issue of difference social classes.

In fact, Oates has implied the difficulty in subverting the rigid hierarchy of social identities. Seigl has a strong awareness of social distinction though he treats people of low class gently and generously. When Seigl has dinner with Sondra in the Café, he wonders how Dmitri can "humble himself in the role of waiter" and "servant" and how he can work "with a smile" in the "demeaning role" (Oates, 2004, p. 52). In addition, when Seigl feels he is sexually charged, Seigl has no interest in his assistant Alma. What Oates wants to express here is that Alma's love is unrequited. Alma is greatly disillusioned with the rigidity of social identity especially when she peers through the door way into the dining room that is occupied by people of middle class. Seigl sits at the head of the table and Professor Sondra Blumenthal is seated to his right. The dining room can be likened to a class society with clear-cut boundaries of social identity. Oates's decision to place the two characters in a position of authority over the lower class is significant: Alma's dream of love and marriage is crushed by her social position. The lower group's aspiration for the dissolution of social boundaries and fluidity of identities is nothing but utopian idealism. When Alma's dream is crushed, her accumulated hatred turns into destructive power reaching the breaking point. In the end of the story, the deaths of the two characters tend to show the incompatible conflicts among social classes.

\section{Conclusion}

Centering on the issue of social identity, The Tattooed Girl reveals its thematic concern with social class conflict. In the text, Oates has describes how the lower class with a subordinate social identity experiences the personal struggles, how the middle class with a privileged social identity undergoes spiritual suffering due to the traumatic memory of history, and how the subordinate social class makes a utopian effort to break social identity boundary, which brings out the deaths of the characters.

\section{References}

Bender, T. (1987). Joyce Carol Oates: Artist in residence. Bloomington: Indiana University Press.

Daly, B. (1996). Lavish self-divisions: The novels of Joyce Carol Oates. Jackson: University Press of Mississippi.

Fiedler, L. (1966). Love and death in the American novel (rev. ed.). New York: Stein and Day.

Cavallaro, D. (2001). Critical and cultural theory: Thematic variations. London: The Athlone Press.

Creighton, J. (1979). Joyce Carol Oates. New York: Twayne.

Friedman, E. (1980). Joyce Carol Oates. New York: Ungar.

Farry, E. (2004). P. S. Section. "Behind the scenes of The Tattooed Girl”. The Tattooed Girl (pp. 10-13). London: Harper Perennial. Johnson, G. (1998). Invisible writer: A biography of Joyce Carol Oates. New York: The Penguin Group.

Oates, J. C. (2004). The tattooed girl. London: Harper Perennial.

Turner, J. (1999). Some current issues in research on social identity and self-categorization theories. In N. Ellemers (Ed.), Social identity (pp. 6-34). Oxford: Blackwell. 